\title{
Analysis of the Motive for the Use of LNG-Powered Ships in the Inland Waters of Yangtze River
}

\author{
Hongyan $\mathrm{Wang}^{1}$ and Zhenjun $\mathrm{Lu}^{2}$ \\ 1. Security Environmental Protection Research Center, China Waterborne Transport Research Institute, Beijing 100088, China \\ 2. Ship Survey Section, Nantong Local Maritime Safety Administration, Nantong 226001, China
}

\begin{abstract}
The fuels that hardly pollute water body and atmospheric environment during burning are regarded as clean fuels. Liquefied Petroleum Gas (LPG), Compressed Natural Gas (CNG) and Liquefied Natural Gas (LNG) are three representative clean fuels that are widely used in the shipping industry. From both ecological and economic point of view, LNG is treated as the best fuels in shipping industry by the ship-owners and Chinese government. In this paper, the wide applications of LNG-powered ships are analyzed from three aspects, including the global energy source structure, economic demands and the formulation of international conventions. Also, the functions of relevant domestic policies on how to accelerate LNG-powered ships widely used in inland waters of Yangtze river, China are summarized. At last, the reasons of the use of LNG-powered ships in inland waters of China in recent years under the impulsion of various factors are discussed in the end.
\end{abstract}

Key words: LNG-powered ships, Yangtze river, environmental protection.

\section{Introduction}

In order to respond to the decisive deployment of the state council about building the Yangtze river economic zone relying on the Yangtze river golden waterway, the construction of Yangtze river waterway stays in the steady development stage. Yangtze river, as the first golden waterway of inland waters with freight volume ranking the first all over the world, undertakes the turnover of cargoes shipped via inland waters in China. In 2013, the freight volume was 1.855 billion tons and cargo turnover up to 704.4 billion tons per kilometer via inland waters of Yangtze river, covering $55 \%$ and $49 \%$ of the nationwide waterway freight volume respectively [1]. Oily water and air contaminants resulted from ships also rise unavoidably because of the increase of cargo turnover and the total discharge of oily water and aerial pollutant is also extremely considerable due to ships centralizing at ports of Yangtze river. Therefore, a clean energy source is extremely important during reduction of the pollution to water body and air.

Corresponding author: Hongyan Wang, master, research field: environmental protection. E-mail: 243079089@qq.com.

\section{Material and Methods}

\subsection{Change of Global Energy Source Structure}

Because of excessive exploitation, petroleum is suffering from the challenge of increasing deficiency. According to the BP world energy source statistics [2], the proved global petroleum reserves is up to 168.79 billion barrels, which is only sufficient to meet 53.3 years of global production at the current exploitation speed. Recently, the emergence of shale gas, tight oil, super-deep underwater petroleum and renewable energy sources has changed the global energy source structure, so, the fuel energy source is no longer limited to petroleum, gaseous fuel (natural gas), renewable energy sources and unconventional fossil fuel cover a greater proportion of energy source consumption, which therefore, reduces the dependence of ships on petroleum greatly.

In 2013, the proved global natural gas reserves was 185.7 trillion cubic meters ( $\mathrm{tcm}$ ), which was sufficient to meet 55.1 years of global production based on the current exploitation speed. In the Middle East and the Central and South America region, there were the 
maximum and minimum natural reserves which had been ascertained, covering $43.2 \%$ and $4.1 \%$ of the global total reserves respectively [3]. The proved natural gas reserves was $15.2 \mathrm{tcm}$ in the Asia-Pacific region, only covering $8.2 \%$ of the global total reserves, additionally, the proportion of reserves to production $(\mathrm{R} / \mathrm{P})$ was lower, so, the natural gas for daily life and production still needed to be imported in quantity for this region. The import volume of LNG was up to 238.1 billion cubic meters $(\mathrm{bcm})$ in the Asia-Pacific region in 2013, covering $70 \%$ of global LNG imported, it was the largest LNG import region all over the world, thereinto, the import volumes of LNG in China, Japan and Korea were $24.5 \mathrm{bcm}, 119 \mathrm{bcm}$ and 54.2 bcm respectively. BP outlook 2035 predicts China will be the second largest LNG import country in the train of Japan (13 Bcf/d) by 2035 , with import volume up to $12 \mathrm{Bcf} / \mathrm{d}$ [2].

The exploitation of natural gas has changed the global energy source structure and become a cause for the rapid development of LNG-powered ships at home and abroad, while the Asia-Pacific region still depends on import of a plenty of LNG to meet the energy source demands. Shipping industry, as one of the main industries of energy source consumption, drives the development of Liquefied Natural Gas (LNG), which is an inevitable demand for shipping development.

\subsection{Inherent Requirement for Shipping Economy}

2.2.1 Environmental Protection Property of LNG Fuel-Reduction of Air Pollution via LNG Fuel

For the purpose of reducing shipping cost, a heavy fuel oil with comparatively lower price is always selected as ship driving fuel for a ship owner. Such heavy fuel oil contains a lot of bitumen, carbon, sulfur and metal compounds, which inevitably generate multiple atmospheric pollutants during burning. According to statistics, carbon dioxides, sulfur oxides and nitrogen oxides annually discharged from ships cover $6 \%, 20 \%$ and $30 \%$ of the global total discharge amount respectively [4]. Ship pollutants affect ports and the quality of air along them seriously, which should not be neglected. A clean energy source as ship-driving fuel is assuredly emergent for the purpose of reducing the pollution of ship discharge to seas and air along rivers. Natural gas, with methane as main ingredient, only generates a little $\mathrm{CO}_{2}$ and nitrogen oxides with few sulfur oxides during sufficient burning, so, it is widely known and popularized in the shipping industry, instead of ship fuel.

\subsubsection{Reduction of Oil Pollution via LNG Fuel}

With the improvement of shipping conditions and the increase of tonnage of ships in Yangtze river waterway, the power of mechanical equipment rises accordingly, especially the application of large-power diesel engine to a ship incurs that the oil content in water at the ship bilge increases as well. If the bilge water is treated improperly and drained out of the shipboard, the water body will be polluted seriously. Moreover, there are more sensitive resources in Yangtze river economic zone where the self-cleaning capacity of the water body is weaker, the sensitive areas include the most upstream Dianchi lake, Erhai lake, Lugu lake and other lakes and reservoirs in Yunnan province; the most downstream Taihu lake, Hangjiahu lake as well as the north-south Grand Canal region, etc.. Consequently, the optimal method is to popularize LNG ships and take water lubrication technology instead of the traditional lubrication if completely getting rid of oil pollution and atmosphere pollution from ship.

\subsection{Economical Efficiency of LNG Fuel}

From the economic efficiency, the price of LNG on the current market is up to about $3 / 4$ of the diesel oil, the price of natural gas per cubic meter approximately equals to that of a liter of diesel oil, if burning is available according to the LNG-diesel oil proportion of 7:3, the cost of ship after using LNG reduces by about $25 \%$ [5]. In accordance with the analyses in "discussion on the application of LNG to inland waterway field of China" [6], a 3,000 t cargo ship 
perennially sailing from Wuhan to Shanghai can save fuel cost up to 445 thousand Yuan every year after using double fuels including LNG and diesel oil, and such ship can recover its cost within a year besides the construction expense of 500,000 Yuan. Accordingly, in comparison with diesel oil powered ship, LNG-powered ship is economical soundly.

\subsection{Gas Supply Guarantee of LNG Fuel}

Due to the uneven distribution of natural gas all over the world, various regions need to rely on the import and export of natural gas to keep demands balanced, which therefore motivates the establishment of LNG receiving stations all over the world. Relevant statistics reveal that, by the end of 2013, the number of domestic LNG gas stations had increased to more than 2,000, and it is predicted that there will be an increase of more than 10,000 domestic LNG filling stations from 2015 to 2020 . In terms of the guarantee of liquefied natural gas supply, natural gas supply facilities are widely distributed to meet the regional demands for liquefied natural gas.

Comprehensively considering the natural gas's environmental protection, economy efficiency, natural gas supply guarantee and other reasons, the use of a liquefied natural gas ship can effectively improve the economic benefits of the ship operation. Therefore, the popularization of LNG ships can greatly meet the inherent requirements for the shipping economy.

\subsection{Promotion of the Convention on the International Maritime Organization}

2.5.1 Promotion of MARPOL Supplementary Provision VI

The International Maritime Organization (IMO) passed the MARPOL supplementary provision VI in July 2011, which raises the standards for emission of ship's nitrogen oxides $\left(\mathrm{NO}_{\mathrm{x}}\right)$ and sulfur oxides $\left(\mathrm{SO}_{\mathrm{x}}\right)$ [6]. The Convention requires that the sulfur content of ship fuels must be less than $0.5 \%$ by 2020 for those ships entering Baltic sea, the North sea and the coastal waters of North America and Caribbean sea where Emission Control Areas (ECA) are established, the sulfur content must be less than $0.1 \%$ by 2015 [7].

For the emission standards of $\mathrm{NO}_{\mathrm{x}}$, the 66th session of Marine Environment Protection Committee (MEPC) explicitly indicates the $\mathrm{NO}_{\mathrm{x}}$ TierIII standard will be implemented for all the ships entering the ECAs of North America and Caribbean sea in America since January 1, 2016. For New Emission Control Areas (NECA) designated in future, the committee stipulates: ships constructed on or after the day when a new ECA is designated, or on the date later than the specified in the amendment of ECA or later (the later date is chosen), should conform to the TierIII standard.

2.5.2 Promotion of International Gas Fueled Ship Safety Rules

In order to reduce the pollution of $\mathrm{SO}_{\mathrm{x}}, \mathrm{NO}_{\mathrm{x}}, \mathrm{CO}_{2}$ and suspended particulates (PM 2.5, etc.) emitted by gas fueled ships to the environment, IMO held the first meeting of "cargo and container transportation committee" (CCC) in London from September 8, 2014 to September 12, 2014, where the rules for safety of the international gas fueled ships (the IGF rules, hereinafter referred to as "the rules") were reviewed and finalized, which were passed on the 95th maritime safety committee of the International Maritime Organization (IMO MSC95) and will take effect on January 1, 2017 [8]. The rules are designed to establish mandatory provisions (including monitoring provisions) for the systematic arrangement, installation, and testing of machinery and equipment used for the gas fueled ship, in order to become the basis for the design, construction and use of such ship.

The raise of emission standards for ship $\mathrm{NO}_{\mathrm{x}}$ and $\mathrm{SO}_{\mathrm{x}}$ in MARPOL supplementary provision VI and the formulation of IGF rules [8] incur that the application of ordinary fuel vessels to the shipping industry falls into a dilemma, which therefore accelerates the transformation speed of ships taking LNG as driving fuel. 


\subsection{Driving of National Policies}

2.6.1 The Latest Regulations Regarding the Use of LNG Powered Ships in Inland Waters

In order to promote the safe use of the LNG fuel ships in inland waters, only in December 2014 did China maritime bureau issue three provisions on LNG-powered ship:

(1) The safety supervision and management regulations on LNG fuel ships in inland rivers [9] aims to supervise and manage inland river LNG-powered ships sailing, anchoring, operating and engaging in traffic safety activities in navigable inland waters of the People's Republic of China;

(2) The notice of relevant items on promoting the application of liquefied natural gas as ship fuel [10] proposes the inspection certificate and pilot requirements for the application of LNG fuel to ships in inland waters and definitely prescribes the design and reconstruction requirements for ships and ship safety management;

(3) Provisional rules for safety supervision and management on water liquefied natural gas filling stations [11] proposes the establishment and site selection requirements for filling stations, advocates on the management on the safety and pollution prevention of fuel ships and stipulates the emergency response procedures for filing stations.

2.6.2 The Latest Regulations Regarding the Use of LNG-Powered Ships in Yangtze River

The rapid growth and utilization of shale gas in the world has a great impact on China, which motivates the popularization and application of fuel ships in inland waters, lakes and reservoirs. In 2014, the state council issued "the state council's guidance on promotion of the development of the Yangtze river economic zone" to establish the Yangtze river as the golden waterway of China. The guidance aims to create a green energy source industry zone along the Yangtze river, to construct state-level demonstration zones for the comprehensive development of shale gas, and to push forward the construction of coastal liquefied natural gas receiving stations, so as to strictly control and govern water pollution in the Yangtze river.

On November 18, 2014, the ministry of transport publicized the list of the first batch of pilot demonstration projects on the application of LNG to water transportation industry, in which pilot projects in the Yangtze basin include:

(1) The comprehensive LNG pilot project for backbone ships of Sinotrans \& CSC Holdings Co., Ltd along the trunk line of the Yangtze river: it is proposed to build two LNG-powered ships which are applied to inland waters along the trunk line of Yangtze river, construct LNG filling station and LNG loading/unloading dock at the supporting pilot of Huanggang, Hubei province, as well as onshore water/land LNG filling station at the pilot site of Yichang, Hubei province;

(2) Sinopec's "oil and gas combination" pontoon style LNG filling station construction pilot project along the trunk line of the Yangtze river: it is proposed to build two pontoon style LNG filling stations with "oil and gas combination";

(3) Onshore LNG filling station and LNG transshipment station pilot project of ENN energy holdings limited along the middle-lower reaches of the Yangtze river: it is proposed to construct an onshore LNG filling station along the trunk line of Yangtze river, research and bring forward LNG filling station service standards for ships along the trunk line of Yangtze river.

\section{Results and Discussion}

GL DNV data show that the global LNG-powered ships will reach nearly 1,800 in 2020 . In the next three years, 37 LNG-powered ships will be put into operation, and the reconstruction of 2 LNG-powered ships will be completed within three years. According to Lloyd's prediction, the LNG fuel will reach $11 \%$ of the market share maximally by 2030 [12].

Due to China's complex navigation ships sailing in 
inland waters of China and obsoleted ship equipment, different from European and American countries which are dominated by new-built ships, China mainly focuses on the reconstruction of fuel powered system with regard to the popularization of LNG-powered ship. Namely, a flammable LNG hybrid combustion system is added without changing the original diesel oil engine structure to form a diesel oil-LNG hybrid system. Compared with the single fuel-powered system, the energy-saving and emission reduction of the dual fuel powered system mainly represent such aspects as reduction of noise pollution, reduction of dust and waste oily water discharge, reduction of sulfur oxides discharge up to $80 \%-90 \%$, as well as carbon dioxide emission up to $15 \%-20 \%$ [13]. In April 2015, the first two LNG dual fuel powered ships named "Shandong Zaozhuang Cargo Ship 2662" and "Shandong Zaozhuang Cargo Ship 3666" successfully launched for trial sailing in Zaozhuang city, which realized the "0" breakthrough of inland river shipping clean energy source ship in Shandong province.

Considering the safety hazard of the dual fuel powered ship, pure LNG-powered ships were put into operation in China's inland rivers in 2015, really realizing the fuel oil substitution rate of $100 \%$. On March 5, 2015, China's first pure LNG-powered ship named "Green Power 6002" had a successful sailing trial, which adopted pure LNG fuel engine as main propulsion mainframe, reaching $25 \%$ reduction of the carbon dioxide emissions, $90 \%$ reduction of nitrogen oxide emissions and zero emission of sulfur oxides, PM 2.5, oily water and domestic sewage. So, it is regarded as a real clean ship [14]. Since March in this year, the first three pure LNG-powered ships have been constructed in Yancheng, Jiangsu province. Once they are put into operation, the fuel costs will reduce by $30 \%$ at most, and LNG burning can reduce the nitrogen oxides emission up to $39 \%$ and carbon dioxide emission up to $90 \%$. Since March 28, Shanghai Green Power Water Transport Co., Ltd. (hereinafter referred to as the "Green Water Transport") has begun to construct the first 200 LNG-powered ships, which emblematizes the commencement of a large-scale renewal of inland river water transportation tool.

\section{Conclusions}

In summary, four conclusions are educed as follows, aiming at the cause analyses of the wide popularization and use of LNG-powered ship in the inland river of the Yangtze river:

(1) The development and utilization of natural gas has changed the global energy source structure, reduced the dependence of ship fuels on petroleum, which becomes one of the causes for the rapid development of LNG-powered ships at home and abroad;

(2) In comparison with ordinary fuels, LNG, as ship driving fuel, reduces the burden on the environment during use. The higher performance price ratio of LNG meets the benefits of ship owners, the wide distribution of natural gas supply facilities and the establishment of large-scale LNG receiving stations meet the inherent requirements for the shipping economy, which lays solid foundations for the rapid development of LNG-powered ships in the inland rivers of China;

(3) With the increase of emission control areas in recent years, much stricter rules for the emission of

Table 3 Natural gas distribution in China, Asia-Pacific region and the whole world.

\begin{tabular}{lcccl}
\hline Natural gas & Proved reserves & Production & Consumption & R/P ratio \\
\hline China & 3.3 & 117.1 & 161.6 & 28 \\
Total Asia Pacific & 15.2 & 489 & 639.2 & 31.1 \\
Whole world & 185.7 & 3369.9 & 3347.6 & 55.1 \\
\hline
\end{tabular}

* Source: BP statistical review of world energy June 2014 [3]. 
ship nitrogen oxides $\left(\mathrm{NO}_{\mathrm{x}}\right)$ and sulfur oxides $\left(\mathrm{SO}_{\mathrm{x}}\right)$ are prescribed in MARPOL convention, together with the formulation of relevant safety rules for LNG-powered ships (IGF rules), which accelerates the speed of transformation towards LNG driving fuel;

(4) In accordance with the IGF rules for the safe use of gas-powered ships, China has formulated relevant polices for safety supervision and management on LNG ships, which provide legal bases for the safe use of these ships in the inland rivers of China and the Yangtze river.

\section{References}

[1] Ministry of Transport of the People's Republic of China. 2014. The 2013 Report on China's Shipping Development. China: Communications Press Co. Ltd..

[2] Bob Dubley. 2013. "BP Statistical Review of World Energy June 2014.” World Petroleum Congress, Moscow. Accessed June 16, 2014. http://www.bp.com/statisticalreview.

[3] International Gas Union News. 2014. Views and Knowledge on Gas-Worldwide. World LNG report.

[4] China Classification Society. 2014. Report on IMO MEPC66 Resolution. China: Communication Press Co. Ltd..

[5] Bo, Guo, M. S. 2013. Research on Reliability of LNG/Disel Dual Fuel Marine Power Plant. WuHan: WuHan Technical University.

[6] Shuhui Zhou. 2013. "Prospect of LNG Application to
Inland Water Transportation in China." NATUREGASIND 33 (2): 81-89.

[7] Boyang Li. 2014. "Application and Analysis of Marine LNG Fuel." Ship Electrical Technology Application Study 34 (10): 77-80.

[8] Maritime Safety Committee. 2015. International Code of Safety for Ships Using Gases or Other Low-Flashpoint Fuels. London: The New Mandatory Gas and Low-Flashpoint Fuels Code, IMO.

[9] Maritime Safety Administration of the People's Republich of China. 2014. The Safety Supervision and Management Regulations on LNG Fuel Ships in Inland Rivers. China: The Regulations and Rules in Maritime.

[10] Maritime Safety Administration of the People's Republich of China. 2014. The Notice of Relevant Items on Promoting the Application of Liquefied Natural Gas as Ship Fuel. China: The Regulations and Rules in Maritime.

[11] Maritime Safety Administration of the People's Republich of China. 2014. Provisional Rules for Safety Supervision and Management on Water Liquefied Natural Gas Filling Stations. China: The Regulations and Rules in Maritime.

[12] Nan Zhao, Wenqing Xie, and Qiong Yu. 2014. Report on Global Ports Development. ShangHai International Shipping Research Center Annual report.

[13] Ministry of Transport of the Yangtze Waterway Bureau. 2014. Report on Yangtze River Shipping Development. China: Communications Press Co. Ltd..

[14] Junjie Chen. 2015. "The First Domestic LNG-Powered Vessel Produced." In China Waterborne Transport Newspaper, 1. 